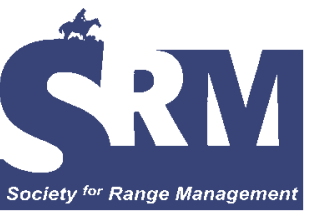

\title{
Famous People and Events in Reno-Tahoe History
}

\section{By Doug Busselman}

he theme of the Society of Range Management 60th Annual Meeting, "Traditions and Transitions," aptly describes the "neighborhood" that conference visitors will be traveling into on Feb-
ruary $10-16,2007$, when they arrive and stay in Reno, Nevada. This is an area with a rich history of famous people and events that played a significant role in the development of the West, and much of their legacy is still apparent and a part of our current culture.

For those inclined to appreciate the history of an area of the country you might be visiting, Reno-Sparks, Nevada, has much to offer and a quick trip to a historical website (www. nevada-history.org) will give you lots of prearrival information to get you started in developing your list of things to do while you're in the Reno-Sparks neck of the woods.

You won't be the first to make a business/pleasure trip to Nevada-explorers such as Peter Skene Ogden and Jedediah Strong Smith were among the first white men to enter the area, in the 1820s.

About 1843, Captain John C. Fremont and a 25-man party arrived at Pyramid Lake (one of the things you might want to visit and take a look at when you come to town-it's roughly 30 miles northeast of Reno). Back then this area was part of Mexico. Fremont and his group, which included a tracker-pathfinder, Kit Carson, moved on with their looksee, traveling down to the Truckee Meadows (now the site of Reno-Sparks). This bunch was not inclined to stay still for long and headed up into the Sierra Nevada Mountains where the Carson River comes out of the mountains. Shortly after this, the Fremont crew became the first white men to see a high mountain lake, now called Lake Tahoe (you'll also want to mark this area on your list of places to visit when you come over in February 2007). It's not known whether the Fremont party took advantage of the combination of snow and moun- tainsides for skiing, but it might be an activity you'll want to try.

Staying too long in the Truckee Meadows (or leaving before you should) is not a new phenomenon. In 1846 an emigrant party, passing through the Truckee Meadows, either stayed too long or left too soon, and ended up stuck in the heavy snows of the Sierra Nevada Mountains. Forty-seven of the 87-person group perished in this ill-fated outing. Today, a mountain pass in California not far from Reno on Interstate I-80 is named after the Donner party.

California has had and continues to have a corollary effect in Nevada. In January of 1848, when James Marshall made his discovery of a very valuable rock at Sutter's sawmill on the South Fork of the American River, the Truckee Meadows became a significant stopover site for those making the trip west on the California Trail. In the days before the RenoSparks Visitors and Convention Authority started keeping track of actual numbers of visitors, estimates of settlers passing through the Truckee Meadows were around 22,500 in $1849,45,000$ in 1850, and over 52,000 in 1852.

In February of 1848, the Treaty of Guadalupe Hidalgo transferred ownership of Nevada from Mexico to the United States.

Traffic through northern Nevada at this time also led to areas of gold and silver exploration on the east side of the Sierra Nevada Mountains. The first Nevada gold discovery was made in Gold Canyon, near Dayton, Nevada (which is located a few miles east of modern-day Carson City).

In 1850, Captain Joseph DeMont and Hampton Beatie were among the first to consider the retail potentials of $\mathrm{Ne}$ vada. This group was associated with Brigham Young, of Salt Lake City, and they set up the first trading post at the site that would become Mormon Station/Genoa. In 1851 this area became the first permanent settlement in Nevada. Ge- 
noa is located in Carson Valley, a few miles south of Carson City on present-day Highway 395.

Although the Genoa community didn't last on a continuous basis after 1851, in July of 1859 those who were around back then held a Constitutional Convention in Genoa.

The same year, about 40 miles south of the Truckee Meadows, the Comstock Lode discovery was made. This discovery triggered a strong and almost overnight urban development project that turned into Virginia City, Nevada. (This is another area you might want to have on your trip itinerary during your visit.)

One of the significant Virginia City business enterprises of this era was the Territorial Enterprise newspaper. This pub- lication had as one of its reporters a writer hoping to get his start in the profession... his name was Samuel L. Clemens, and he also went by the name Mark Twain. Mr Twain will be making an appearance at the 2007 meeting.

Although we can't claim to have the literary track record of that Clemens guy, we hope that this background information will help stimulate your interest in making the trip to the 2007 SRM Annual Meeting, February 10-16. We're looking forward to having you stop by for a visit!

Author is Executive Vice President, Nevada Farm Bureau Federation,dbusselman@aol.com. 